\title{
Pendidikan Kesehatan dalam Rangka Mitigasi dan Adaptasi Menghadapi Wabah Covid-19 di Kabupaten Buton Selatan Provinsi Sulawesi Tenggara
}

\author{
Nur Illiyyin Akib ${ }^{1}$, Halik ${ }^{1}$, Ruslin ${ }^{1}$, Muamal Gadapi \\ ${ }^{1}$ Fakultas Farmasi Universitas Halu Oleo \\ ${ }^{2}$ Fakultas Keguruan dan Ilmu Pendidikan \\ email: nurilliyyinakib@gmail.com
}

\begin{abstract}
Thematic KKN- Thematic Social Work Internship have been carried out in the form of health education for the community in South Buton Regency. This activity aims to increase understanding of health in the context of handling the Corona Virus Disease 19 (Covid-19) outbreak. This activity was carried out in several villages in South Buton Regency. Activities were carried out from June to July 2020. Implementation of activities consisted of counseling on the Gerakan Masyarakat Hidup Sehat (Germas), counseling on the tanaman Obat Keluarga (Toga), and counseling on Perilaku Hidup Bersih dan Sehat (PHBS), as well as disseminating information through social media and mass media. Extension is carried out by lecturing, practice, and question and answer methods. The social media used is Instagram. The mass media used are leaflets. This activity succeeded in increasing understanding of health for the community in South Buton Regency.
\end{abstract}

Keywords: Health education, Counseling, Covid-19, South Buton Regency

\section{Abstrak}

Telah dilaksanakan KKN Tematik dengan tema pendidikan kesehatan bagi masyarakat di Kabupaten Buton Selatan. Kegiatan ini bertujuan meningkatkan pemahaman masyarakat dalam penanganan wabah Corona Virus Disease 19 (Covid-19. Kegiatan ini dilaksanakan di beberapa desa di Kabupaten Buton Selatan pada bulan Juni hingga Juli 2020. Kegiatan dilaksanakan dalam bentuk penyuluhan Gerakan Masyarakat Hidup Sehat (Germas), penyuluhan Tanaman Obat Keluarga (Toga), penyuluhan Perilaku Hidup Bersih dan Sehat (PHBS), serta sosialisasi melalui media cetak dan media sosial. Metode pelaksanaan kegiatan ini adalh ceramah, latihan, dan tanya jawab. Media sosial yang digunakan adalah Instagram. Media cetak yang digunakan adalah leaflet. Kegiatan ini berhasil meningkatkan pemahaman tentang kesehatan pada masyarakat di Kabupaten Buton Selatan.

Kata Kunci: Pendidikan kesehatan, Penyuluhan, Covid-19, Kabupaten Buton Selatan

\section{PENDAHULUAN}

Kemunculan suatu penyakit baru yang disebabkan oleh virus yang menyerang sistem pernapasan di penghujung tahun 2019 disebut novel coronavirus disease 2019 (Covid-19) [1]. Covid-19 diketahui terjadi pertama kali di Kota Wuhan Cina dan menyebar dengan sangat cepat menyebar ke seluruh dunia termasuk Indonesia. Para ilmuwan mempelajari virus ini dan berusaha menemukan cara mencegah penyebaran yang semakin luas dan cepat [2,3]. Covid-19 menyebar melalui tetesan saat penderita bersin atau batuk yang menempel pada objek lain di sekitarnya [4]

Presiden RI menyatakan status Covid19 menjadi tahap Tanggap Darurat pada tanggal 17 Maret 2020. Presiden menerbitkan Keputusan Presiden No. 7 Tahun 2020 tentang Gugus Tugas Percepatan Penanganan Covid-19 yang 
diketuai oleh Kepala Badan Nasional Penanggulangan Bencana (BNPB). Gugus ini bertugas meningkatkan ketahanan nasional di bidang kesehatan; mempercepat penanganan Covid-19 melalui sinergi antar kementerian, lembaga, dan pemerintah daerah; meningkatkan antisipasi perkembangan eskalasi penyebaran Covid-19; meningkatkan sinergi pengambilan kebijakan operasional; dan meningkatkan kesiapan dan kemampuan dalam mencegah, mendeteksi, dan merespons terhadap Covid-19. [5]

Oleh karena itu diperlukan tindakan pencegahan penuluaran Covid-19 melalui pemahaman masyarakat mengenai tindakan pencegahan Covid-19 di Indonesia khususnya di Kabupaten Buton Selatan Provinsi Sulawesi Tenggara.

Kegiatan ini bertujuan membantu pemerintah setempat dalam meningkatkan kesadaran masyarakat untuk mencegah dan melawan virus Covid-19 dengan cara penggunaan masker dan antiseptik dan desinfektan pembunuh virus.

\section{METODE PENGABDIAN}

Kegiatan ini dilaksanakan pada bulan Juni hingga Juli 2020 di Kabupaten Buton Selatan. Metode yang digunakan pada kegiatan pengabdian masyarakat terintegrasi KKN-Tematik ini bertujuan untuk menghasilkan masyarakat yang memahami cara hidup sehat, berperilaku hidup bersih dan sehat, serta memahami penggunaan tanaman obat.

1. Metode ceramah. Metode ini merupakan metode pembelajaran yang dilakukan dengan cara penuturan atau penjelasan yang disampaikan oleh penyuluh secara lisan [6,7]. Metode ini digunakan pada kegiatan penyuluhan Gerakan Masyarakat Hidup Sehat (Germas), penyuluhan Taman Obat Keluarga (Toga), dan penyuluhan Pola Hidup Bersih dan Sehat (PHBS). Metode ini dinilai efektif dalam menyampaikan materi penyuluhan meskipun peran penyuluh lebih dominan dibandingkan peserta. Penyuluh adalah adalah mahasiswa yang telah dilatih oleh dosen pembimbing sehingga memiliki pengetahuan terhadap materi yang dibawakan. Pada berbagai kegiatan di atas, metode ceramah dipadukan dengan metode lainnya yaitu tanya jawab dan latihan.

2. Metode latihan. Metode ini merupakan metode pembelajaran yang dilakukan dengan cara melaksanakan latihanlatihan agar peserta memiliki kemampuan atau keterampilan yang lebih tinggi daripada teori telah dipelajari [8]. Metode ini dilakukan pada penyuluhan penyuluhan Pola Hidup bersih dan Sehat (PHBS). Target metode latihan adalah kecakapan motorik dan mental masyarakat.

3. Metode tanya jawab. Metode ini merupakan metode pembelajaran yang dilakukan dengan cara memberikan pertanyaan yang harus dijawab [7], terutama dari penyuluh kepada keluarga binaan atau sebaliknya. Metode ini dilakukan pada penyuluhan Gerakan Masyarakat Hidup Sehat (Germas), penyuluhan Taman Obat Keluarga (Toga), dan penyuluhan Pola Hidup Bersih dan Sehat (PHBS).

\section{HASIL DAN PEMBAHASAN}

Kegiatan pernyuluhan Germas dilaksanakan pada tanggal 28 Juni hingga 1 Juli 2020 di beberapa desa di Kabupaten Buton Selatan dengan cara pendampingan pada keluarga binaan. Penyuluhan dilakukan dengan memperhatikan protokol kesehatan yaitu memakai masker, menjaga jarak, dan menghindari kerumunan.

Selain itu dilakukan juga sosialisasi melalui media leaflet yang dicetak dan ditempelkan di rumah warga. Serta disebarkan melalui media sosial Instagram.

\section{A. Penyuluhan Gerakan Masyarakat Hidup Sehat (Germas)}


1. Makanan Bergizi Seimbang

Kecukupan gizi sangat diperlukan dalam mempertahankan sistem kekebalan tubuh. Meskipun makanan bukan penangkal virus, namun gizi yang baik akan menguatkan sistem kekebalan tubuh sehingga akan memberikan perlindungan ekstra agar tidak tertular Covid-19.

2. Olahraga

Latihan fisik ringan seperti aerobik 30 menit mengaktifkan kerja sel darah putih yang merupakan komponen utama kekebalan tubuh. Idealnya latihan aerobik dilakukan lima kali seminggu. Namun tidak dianjurkan melakukan olahraga berlebihan karena menekan kekebalan tubuh.

3. Menghindari rokok

Beberapa penelitian di Cina menyatakan bahwa konsumsi rokok diasosiasikan dengan prognosa Covid-19 yang buruk. Perokok yang terpapar Covid-19 akan memiliki resiko penyakit lebih berat hingga perlu perawatan di ICU, penggunaan ventilator, sampai resiko kematian. [9]

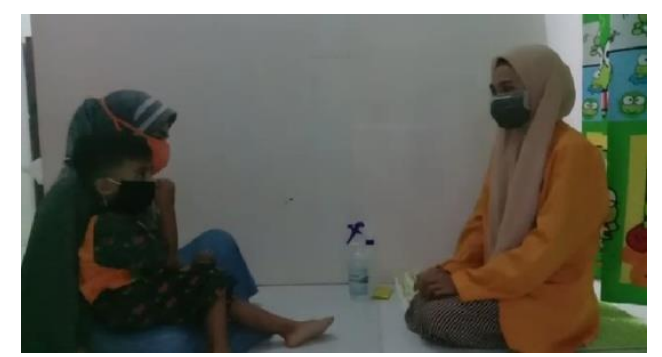

Gambar 1. Penyuluhan Germas kepada keluarga binaan.

Pentingnya penyuluhan Germas agar masyarakat memahami cara hidup sehat yaitu mengkonsumsi makanan bergizi seimbang, melakukan olahraga, dan menghindari rokok. Melalui Germas maka diperoleh peningkatan kekebalan tubuh sehingga dapat memutus rantai penyebaran Covid-19.
B. Penyuluhan Perilaku Hidup Bersih dan Sehat (PHBS)

Salah satu indikator PHBS adalah mencuci tangan yaitu menggosok air dengan sabun di seluruh kulit permukaan tangan dengan kuat dan ringkas kemudian dibilas di bawah aliran air. [10]

Cuci Tangan Pakai Sabun (CTPS) merupakan upaya yang direkomendasikan untuk mencegah penyakit karena sabun mudah diperoleh dan terjangkau. Sabun terdiri dari rantai karbon hidrofobik yang melekat pada mikroba di tangan yang disabuni dan membentuk molekul yang sangat halus. Ketika tangan dibilas air, sabun membawa molekul tersebut bersama mikroba dan air bilasan. [11]

Adapun langkah mencuci tangan pakai sabun dengan benar [12]:

1. Kedua telapak tangan dibasahi memakai air yang mengalir, kemudian diusap dan digosok dengan sabun.

2. Kedua punggung tangan digosok dan diusap bergantian.

3. Jari serta sela-sela jari digosok dan diusap hingga bersih

4. Ujung jari digosok bergantian dengan mengatupkannya

5. Kedua ibu jari digosok dan diputar bergantian

6. Ujung jari diletakkan ke telapak tangan kemudian digosok perlahan

7. Kedua pergelangan tangan dibersihkan dengan cara memutar, diakhiri dengan membilas seluruh bagian tangan dengan mengalir, lalu dikeringkan dengan handuk atau tisu.

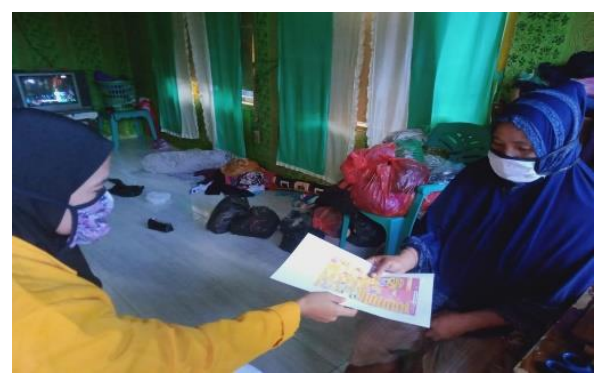


Gambar 2. Penyuluhan PHBS kepada keluarga binaan.

Pentingnya penyuluhan PHBS agar masyarakat memahami cara hidup sehat yaitu membiasakan diri mencuci tangan dengan sabun. Melalui PHBS maka diperoleh peningkatan kekebalan tubuh sehingga dapat memutus rantai penyebaran Covid-19.

\section{Penyuluhan Tanaman Obat Keluarga (Toga)}

Tanaman atau tumbuhan obat berguna mengatasi berbagai penyaki karena memiliki kandungan zat aktif. Termasuk yang berkhasiat meningkatkan sistem kekebalan tubuh sehingga dapat mencegah penularan virus Corona.

Adapun beberapa jenis tanaman yang dapat dimanfaatkan dalam pencegahan Covid-19 adalah:

1. Meniran (Phyllanthus niruri L.).

2. Jahe (Zingiber officinalis)

3. Jambu Biji (Psidium guajava)

4. Kunyit (Curcuma domestica L.)

5. Temulawak (Curcuma xanthorriza Roxb).

Adapun penyiapan pengolahan

Toga adalah:

1. Peralatan dari bahan stainless steel harus dalam kondisi bersih.

2. Simplisia dipisahkan dari kotoran, bahan asing lainnya, bagian yang rusak, dan tumbuhan lain yang tercampur.

3. Simplisia dicuci dengan air bersih mengalir. Bisa juga disemprot dan disikat.

4. Simplisia ditiriskan lalu dipotong atau diiris menggunakan pisau sehingga hasil penyarian yang lebih optimal pada saat perebusan.

5. Simplisia direbus dengan air bersih. Akar, rimpang, kayu, kulit batang, buah atau biji dapat direbus lebih lama untuk menyari zat berkhasiatnya dibandingkan jika yang digunakan bunga dan daun.
6. Simplisia nabati segar/kering direbus dalam air mendidih suhu $90^{\circ} \mathrm{C}$ selama 15-30 menit tergantung kemudahan penyarian. Hasil yang diperileh disebut dekokta.

7. Serbuk kering dapat diseduh dalam satu gelas air mendidih selama 5 menit.

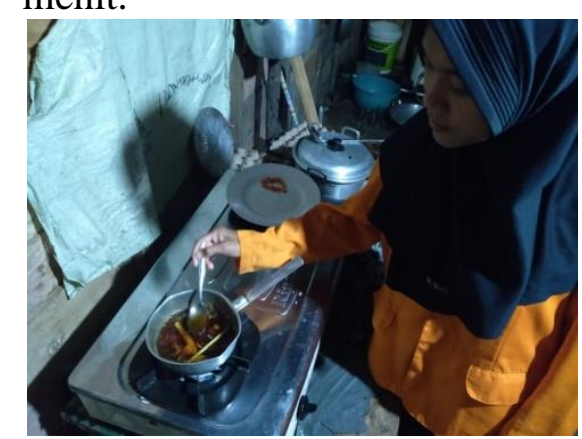

Gambar 3. Penyuluhan Toga kepada keluarga binaan.

Pentingnya penyuluhan Toga agar masyarakat memahami cara penggunaan tanaman obat dalam rangka meningkatkan kekebalan tubuh sehingga dapat memutus rantai penyebaran Covid-19.

Hasil kegiatan Pengabdian pada Masyarakat Terintegrasi KKN-Tematik meliputi:

1. Jumlah keluarga binaan sebanyak 24 KK.

2. Tercapainya tujuan kegiatan yaitu meningkatnya pengetahuan dan sikap masyarakat tentang upaya pencegahan Covid-19.

\section{SIMPULAN}

Penyuluhan dan edukasi melalui media cetak tentang Gerakan Masyarakat Hidup Sehat (Germas), penyuluhan Gerakan penyuluhan Taman Obat Keluarga (Toga), serta penyuluhan Pola Hidup Bersih dan Sehat (PHBS) telah meningkatkan pengetahuan masyarakat terhadap kesehatan khususnya dalam upaya memutus mata rantai penyebaran Covid19. 


\section{UCAPAN TERIMAKASIH}

Terima kasih kepada Universitas Halu Oleo yang telah memberikan Hibah Pengabdian kepada Masyarakat Terintegrasi KKN Tematik Tahun 2020.

\section{DAFTAR PUSTAKA}

[1] World Health Organization (WHO), "Global surveillance for human infection with novel coronavirus (2019-NCOV)", 2020.

[2] C. Sohrabi, Z. Alsafi A., dan N. O'Neill., M. Khan., A. Kerwan, A. al-Jabir, C. Iosifidis, dan R. Agha, "a Review of The 2019 Novel Coronavirus (Covid-19)", International Journal of Surgery, Vol.76(1), 2020.

[3] O.A. Israel, "Covid-19: An International Public Health Concern", Central Journal of Global Health, Vol 9(1), 2020.

[4] World Health Organization (WHO), "Water, Sanitation, hygiene, and waste management for the Covid19 virus". Geneva, Swiss. WHO. 2020.

[5] Gugus Tugas Percepatan Penanganan Covid-19, "Pedoman Penanganan Cepat Medis dan Kesehatan Masayarakat Covid-19 di Indonesia", www.covid19. go.id, 2020.

[6] S. Sagala, "Konsep dan Makna Pembelajaran untuk Memecahkan Problematika Belajar dan Mengajar", Bandung: Alfabeta, 2009.

[7] S.B. Djamarah dan A. Zain, "Strategi Belajar Mengajar", Jakarta: PT Rineka Cipta, 2006.

[8] F. Lesmana, K. Maman, Ariyano, dan K.K. Uli, "Metode Latihan (Drill) untuk Meningkatkan Hasil Belajar Peserta Didik dalam Menggambar Autocad", Journal of Mechanical Engineering Education, Vol 1 (2), 2014.

[9] C. Cheng, Tzu-Ping, C.K. Wen, Hung- jen T, "Severe Acute Respiratory Syndrome Corona-virus 2 (SARSCoV-2) and Corona Virus Disease2019 (Covid-19): The Epidemic and The Challenge", International Journal of Antimicrobial Agents, 2020.

[10] Aswadi, S. Sukfitrianty, Virgilius, dan Surahmawati, "Perilaku Hidup Bersih dan Sehat (PHBS) Pada Siswa-Siswi SDK Rita pada Kecamatan Kota Komba Kabupaten Manggarai Timur Propinsi Nusa Tenggara Timur", $A L$ - SIHAH, Vol. IX(2), 2017.

[11] A.K. Umaroh, Heru Y.H, dan Choiri., "Gambaran Perilaku Hidup Bersih dan Sehat (PHBS) di Wilayah Kerja Puskesmas Bulu Kabupaten Sukoharjo Bulan Januari-Maret 2015", Jurnal Kesehatan, Vol. 1(1), 2015.

[12] W.D Astuti, Zainul K, dan Dewi L., 2011, Perilaku Hidup Bersih Dan Sehat (PHBS) Dalam Rumah Tangga Ibu Hamil Dan Ibu Pernah Hamil Di Indonesia, Buletin Penelitian Sistem Kesehatan, Vol. 14(4) 